\title{
ARNTL wt Allele
}

National Cancer Institute

\section{Source}

National Cancer Institute. ARNTL wt Allele. NCI Thesaurus. Code C119693.

Human ARNTL wild-type allele is located in the vicinity of $11 \mathrm{p} 15$ and is approximately 111 $\mathrm{kb}$ in length. This allele, which encodes aryl hydrocarbon receptor nuclear translocatorlike protein 1, plays a role in the transcriptional activation of genes involved in circadian rhythms. 